\title{
Vitamin D Link to Diabetes and Obesity: Interesting Promising and Opposing Results to Be Followed Up
}

\author{
Mina T Kelleni ${ }^{1,2 *}$ \\ ${ }^{1}$ Department of Pharmacology, College of Medicine, Jouf University, Kingdom of Saudi Arabia \\ ${ }^{2}$ Department of Pharmacology, Minia University, Egypt
}

Submission: July 25, 2018; Published: August 08, 2018

*Corresponding author: Dr. Mina T Kelleni, Department of Pharmacology, Jouf University, Sakaka, Kingdom of Saudi Arabia; Tel: +966560407874, Email: drthabetpharm@yahoo.com

\section{Opinion}

Vitamin D (1,25(OH)2D3), abbreviated also as 25(OH)D is a steroid hormone that has a range of physiological functions in skeletal and no skeletal tissues and besides the effects on bone metabolism, vitamin $\mathrm{D}$ and calcium might contribute to metabolic disorder accompanied by obesity [1,2]. Possible mechanisms include that low vitamin D impairs insulin action, glucose metabolism and various other metabolic processes in adipose and lean tissue $[3,4]$.

Polymorphisms of the vitamin D receptor, a member of the steroid/thyroid hormone receptor superfamily, gene were suggested to play a role in the pathogenesis of type 2 diabetes by influencing the secretory capacity of beta-cells. Further, genetic variants associated with low plasma $25(\mathrm{OH}) \mathrm{D}$ concentrations were shown to be associated with type 2 diabetes and to mediate modestly between obesity and increased risk of diabetes [46]. A potential independent role for vitamin D was suggested in the regulation of glucose metabolism in a setting of obese patients previously unknown to possess glucose metabolism abnormalities [7]. Similarly, a potential protective role of UVRinduced mediators, including vitamin $\mathrm{D}$ and nitric oxide as well as sun exposure in reducing the development of obesity and cardiometabolic dysfunction [8].

Further, low 25(OH)D was correlated with high body fat, glucose levels and decreased insulin sensitivity and considered a potential risk factor for obesity and development of insulin resistance leading to diabetes type 2 [9] and within a crosssectional, nationally representative sample, abdominal obesity and insufficient 25(OH)D were shown to interact synergistically to influence the risk of insulin resistance [10]. However, while, higher values of total abdominal fat at the L2-L3 intervertebral level were associated with low 25(OH)D levels in Asian-Indian obese subjects without diabetes [11]; 25(OH)D levels were lower in prediabetic and diabetic than normoglycemic subjects and vitamin D deficiency was found to be associated more with carbohydrate metabolism than with obesity [12], other researchers showed vitamin D levels to be neither related to obesity in diabetic as well non-diabetic Asian-Indian individuals nor to weight, fat mass or waist circumference in type 2 diabetic obese vitamin D deficient participants of Arab ethnicity after one year of vitamin D supplementation $[13,14]$. Ongoing research would inevitably elucidate the masked mechanisms and the reasons for infrequent difference in therapeutic responses.

\section{References}

1. Candido FG, Bressan J (2014) Vitamin D: link between osteoporosis, obesity, and diabetes? Int J Mol Sci 15(4): 6569-6591.

2. Kuroda M, Sakaue H (2016) Role of vitamin D and calcium in obesity and type 2 diabetes. Clin Calcium 26(3): 349-354.

3. McGill AT, Stewart JM, Lithander FE, Strik CM, Poppitt SD (2008) Relationships of low serum vitamin D3 with anthropometry and markers of the metabolic syndrome and diabetes in overweight and obesity. Nutr J 7: 4.

4. Reis AF, Hauache OM, Velho G (2005) Vitamin D endocrine system and the genetic susceptibility to diabetes, obesity and vascular disease. A review of evidence. Diabetes Metab 31(4 Pt 1): 318-325.

5. Afzal S, Jacobsen P, Bojesen SE, Nordestgaard BG (2014) Vitamin D concentration, obesity, and risk of diabetes: a mendelian randomisation study. Lancet Diabetes Endocrinol 2(4): 298-306.

6. Speer G, Cseh K, Winkler G, Vargha P, Braun E, et al. (2001) Vitamin D and estrogen receptor gene polymorphisms in type 2 diabetes mellitus and in android type obesity. Eur J Endocrinol 144(4): 385-389.

7. Bellan M, Guzzaloni G, Rinaldi M, Ferrari C, Pirisi M, et al. (2014) Altered glucose metabolism rather than naive type 2 diabetes mellitus (T2DM) is related to vitamin D status in severe obesity. Cardiovasc Diabetol 13: 57.

8. Gorman S, Lucas RM, Allen- Hall A, Fleury N, Feelisch M (2017) Ultraviolet radiation, vitamin D and the development of obesity, metabolic syndrome and type-2 diabetes. Photochem Photobiol Sci 16(3): 362-373

9. Grineva EN, Karonova T, Micheeva E, Belyaeva O, Nikitina IL (2013) Vitamin D deficiency is a risk factor for obesity and diabetes type 2 in women at late reproductive age. Aging (Albany NY) 5(7): 575-581. 


\section{Current Research in Diabetes \& Obesity Journal}

10. Kabadi SM, Lee BK, Liu L (2012) Joint effects of obesity and vitamin D insufficiency on insulin resistance and type 2 diabetes: results from the NHANES 2001-2006. Diabetes Care 35(10): 2048-2054.

11. Bhatt SP, Misra A, Sharma M, Guleria R, Pandey RM (2014) Vitamin $\mathrm{D}$ insufficiency is associated with abdominal obesity in urban Asian Indians without diabetes in North India. Diabetes Technol Ther 16(6): 392-397.

12. Clemente-Postigo M, Serrano M, Castillo D, Camargo A, Cardona F, et al. (2015) Serum 25-hydroxyvitamin D and adipose tissue vitamin

his work is licensed under Creative Commons Attribution 4.0 Licens

DOI: $10.19080 / C R D O J .2018 .08 .555734$
D receptor gene expression: relationship with obesity and type 2 diabetes. J Clin Endocrinol Metab 100(4): E591-E595.

13. Gupta A, Aslam M, Rathi S, Mishra BK, Bhardwaj S, et al. (2018) Association of Vitamin D Levels and type 2 Diabetes Mellitus in Asian Indians is Independent of Obesity. Exp Clin Endocrinol Diabetes.

14. Sadiya A, Ahmed SM, Carlsson M, Tesfa Y, George M, et al. (2016) Vitamin D3 supplementation and body composition in persons with obesity and type 2 diabetes in the UAE: A randomized controlled double-blinded clinical trial. Clin Nutr 35(1): 77-82.

\section{Your next submission with Juniper Publishers will reach you the below assets}

- Quality Editorial service

- Swift Peer Review

- Reprints availability

- E-prints Service

- Manuscript Podcast for convenient understanding

- Global attainment for your research

- Manuscript accessibility in different formats

( Pdf, E-pub, Full Text, Audio)

- Unceasing customer service

Track the below URL for one-step submission https://juniperpublishers.com/online-submission.php 